\title{
Biometric measurements of the nasal area of newborns for the development of a nasal protector model: cross-sectional study*
}

\author{
Medidas biométricas da região nasal de recém-nascidos para \\ desenvolvimento de modelo de protetor nasal: estudo transversal \\ Mediciones biométricas de la región nasal de neonatos para el desarrollo \\ de un modelo de protector nasal: estudio transversal
}

How to cite this article:

Mascarenhas MLVC, Guedes BLS, Ferreira MMB, Santos MKO, Santos RCS, Lúcio IML. Biometric measurements of the nasal area of newborns for the development of a nasal protector model: cross-sectional study. Rev Esc Enferm USP. 2021;55:e03706. doi: https://doi.org/10.1590/S1980-220X2019031703706

\author{
Mércia Lisieux Vaz da Costa \\ Mascarenhas ${ }^{1}$ \\ Bruna Luizy dos Santos Guedes ${ }^{1}$ \\ Marcella Martins Barbosa \\ Ferreira $^{2}$ \\ (D) Magda Kelanny de Oliveira dos \\ Santos $^{3}$ \\ Degina Célia Sales Santos ${ }^{1}$ \\ D Ingrid Martins Leite Lúcio ${ }^{1}$
}

* Extracted from the dissertation: "Modelo de protetor nasal para recém-nascidos em uso de pronga: estudo baseado em medidas anatômicas", Universidade Federal de Alagoas, 2017.

${ }^{1}$ Universidade Federal de Alagoas, Escola

de Enfermagem, Maceió, AL, Brazil.

${ }^{2}$ Universidade Estadual de Ciências

da Saúde, Maceió, AL, Brazil.

${ }^{3}$ Escola de Governo em Saúde Pública

de Pernambuco, Caruaru, PE, Brazil.

\section{ABSTRACT}

Objective: To correlate the biometric measurements of the nasal area of premature and term newborns to provide parameters for a nasal protector model. Method: A crosssectional descriptive study, carried out in the neonatal joint accommodation, intermediate and intensive care units of a hospital in Maceio, Alagoas, with a total of 300 newborns, divided into two groups: 150 term and 150 premature. Neonatal history data and 1200 digital photographs were used for biometric measurements. Results: The groups were homogeneous regarding gender, weight and length of the newborn. The measurements of nasal width, distance from the wing of the nose to the right and left columella midline, right and left nasal introitus area, length of the right and left nasal dorsum were different when compared in groups according to gestational age and weight ranges - very low weight, low weight and appropriate weight for gestational age $(\mathrm{p}<0.05)$. Conclusion: The data obtained provide parameters for creating a nasal protector for newborns using prongs, considering anatomical aspects.

\section{DESCRIPTORS}

Infant, Newborn; Nose; Protection; Technology; Neonatal Nursing.
Corresponding author:

Bruna Luizy dos Santos Guedes

Universidade Federal de Alagoas,

Escola de Enfermagem

Av. Lourival Melo Mota, s/n -

Cidade Universitária

CEP 57072-900 - Maceió, AL, Brazil

bruna.guedes89@gmail.com
Received: 10/04/2019

Approved: 03/16/2021 


\section{INTRODUCTION}

The high rate of premature births has demanded the use of Non-Invasive Mechanical Ventilation (NIMV) as a therapy for respiratory disorders. NIMV can happen by providing negative or positive pressure, the positive one being performed continuously or intermittently (Continuous Positive Airway Pressure - CPAP, and Positive Airway Pressure with two pressure levels - BiPAP, respectively) ${ }^{(1)}$.

The nasal prong is one of the most used interfaces for the application of NIMV, with low resistance among its advantages ${ }^{(2)}$. Currently, prongs are used "due to their simple way to manage positive pressure, less invasive, available in different sizes and made of light and flexible material" ${ }^{\prime 3}$. However, "one of the complications of its application is the nasal wound, ranging from edema to necrosis, which can occur with the use of all types of nasal prongs" ${ }^{\prime(3-4)}$.

This type of injury related to the use of nasal prongs fits the definition presented by the National Pressure Ulcer Advisory Panel (NPUAP), which classified as injury by pressure related to medical device any injury caused by devices designed and applied for diagnostic and therapeutic purposes, and the resulting pressure injury is generally in line with the standard or shape of the device ${ }^{(5)}$. A study carried out in a neonatal unit in the city of Maceió, Alagoas state, which identified the presence of nasal lesions related to the use of CPAP, found that all 147 newborns (NB) presented nasal injury to some degree (mild, moderate or severe) with only two days of using that device. It is observed in the clinical practice of nursing care that the incidence of nasal injury due to the use of CPAP has been decreasing with the use of protectors in this area ${ }^{(6)}$.

However, the literature does not report the risks associated with the standardization of the nasal protector and/or the correlation between the type/use of the nasal protector, although the studies point out the main injuries and complications of this therapy ${ }^{(6-7)}$. In order to provide relief and prevent nasal injuries, the use of skin barrier protective dressings based on hydrocolloid, polyurethane and silicone has configured alternatives for professionals who provide health care to these newborns ${ }^{(8)}$.

However, there is a lack and/or little standardization as to the type of material, protector format and usage protocols. Furthermore, the lack of studies that consider the anatomical aspects of newborns in the development of technology for these protectors justified the realization of this study, which proposed to answer the following research question: What are the biometric measures of the nasal area of premature and term newborns for the development of nasal protector?

Thus, the objective was to correlate the biometric measurements of the nasal area of premature and term newborns and provide parameters for a model of nasal protector.

\section{METHOD}

\section{TYPE OF STUDY}

This is a descriptive cross-sectional study. Its nature is considered to be applied and of technological production, as it aims at the production of knowledge for the purpose of practical application aimed at solving specific problems, and the interest of this research is the proposition of a technology $y^{(9)}$.

\section{Population}

The sample consisted of 300 newborns, 150 of whom were Pre-Term Newborns (PTNB) (born up to 36 weeks and 6 days) and 150 Term Newborns (TNB) (born between 37 weeks and 41 weeks and 6 days), admitted to a teaching hospital in Alagoas, in the Neonatal Intensive Care Unit (NICU), Conventional Neonatal Intensive Care Unit (CNICU), Kangaroo Neonatal Intermediate Care Unit (KNICU) and in the Joint Housing (JH).

\section{SELECTION CRITERIA}

The following eligibility criteria for participation in the study were considered: NB who did not use any nasal or therapeutic device that compromised the visualization of the nose structures and who presented a stable clinical status regarding the parameters of heart rate, respiratory rate and oxygen saturation, in addition to the no use of oxygen therapy at the time of data collection and who had no nasal malformation.

The sampling was non-probabilistic, for convenience, and the sample of 300 newborns was estimated based on the average number of hospitalizations.

\section{Data ColleCtion}

Data collection took place through photographic records and the other variables using a data collection instrument directly from the medical record, considering the following variables: identification, gender, gestational age, $\mathrm{NB}$ weight (at birth and on the day of collection), Apgar index, age, length of the newborn, type of delivery. All newborns were photographed in four positions: anterior frontal view, nasal base, left and right lateral view. In order to standardize the photographs and guarantee the quality of the records, the same operator was maintained and a support for the photographic camera was used, which maintained a uniform distance between the face of the newborn and the photographic lens.

The variables regarding the biometric measurements of the newborn's face obtained by photographic records were as follows: nasal height (from the height of the eyes to the base of the nose), nasal width (distance between the wings of the nose at the point of maximum expansion), distance from the wing of the nose to the right and left columellar midline (CML), length of the columella (distance between the base of the columella and the level of connection of the tip of the nostrils), width of the columella, area of the right and left nasal introitus ${ }^{(10)}$, protrusion of the nasal tip (measured from the alar fold to the nasal tip), length of the right and left nasal dorsum (measured from the root to the nasal tip).

NBs were classified according to weight: very low for age, when located on the curve between $1000 \mathrm{~g}$ and $1500 \mathrm{~g}$; low weight, when it is located on the curve below $2500 \mathrm{~g}$; and adequate weight for age $>2500 \mathrm{~g}^{(11)}$, based on the WHO $\mathrm{z}$-score scale ${ }^{(12)}$. This classification occurred according to the weight found on the day of collection and corrected age. 
The photographs were analyzed with the aid of two softwares, CorelDraw and ImageJ 1.50i, to mark the anatomical points and to measure the biometric measurements, respectively.

\section{DatA ANALYSIS}

Data analysis was performed by measuring lengths, diameters and area of anatomical regions of the newborn's face, marked with the use of the CorelDraw software and with the aid of the image analysis application ImageJ, version 1.50 , to measure the distances between the points. The data were tabulated using Excel for Windows ${ }^{\circledR}$ (2013) and Statistical Package for the Social Sciences ${ }^{\circledR}$ (SPSS) Version 21, the results being presented in tables. They were described in absolute, relative, mean and standard deviation frequencies. A 95\% confidence interval was considered, which reflects a significance level of 0.05. To compare variables between groups, the Kruskal-Wallis test, Anova and Student's t test were used.

\section{ETHICAL ASPECTS}

The study took place after approval of the project by the Research Ethics Committee, with protocol number 1.718.158, in September 2016, respecting the precepts of
Resolution No. 466, of December 12, 2012, of the National Health Council/Ministry of Health, and with authorization from the Institution.

To participate in the research, the parents and/or guardians of the NB received the necessary explanations about what the participation in the study consisted of, which involved everything from the collection of data directly from the medical record to the photographic record of the NB, performed in the presence of the parents and/or guardians. Therefore, the Informed Consent Form (ICF) was signed.

\section{RESULTS}

The digital database was composed of 1200 images of 300 newborns, of which 150 were PTNB and 150 RNT. Of the PTNBs, 70 (23.3\%) were female and $80(26.7 \%)$ were male, as well as of the TNB, 75 (25\%) were women and 75 (25\%) men.

Regarding the type of delivery, one observed that 76 (50.6\%) of PTNB were born from vaginal delivery and 74 (49.4\%) from cesarean. In the term newborns, 77 (51.4\%) were born by vaginal delivery and $73(48.6 \%)$ by cesarean. The mean gestational age in the PTNB was 35.18 weeks, while in the TNB it was 39.52 weeks (Table 1 ).

Table 1 - Characterization of newborns regarding the characteristics of the patient at birth and on the day of the photographic record - Maceió, AL, Brazil, 2017.

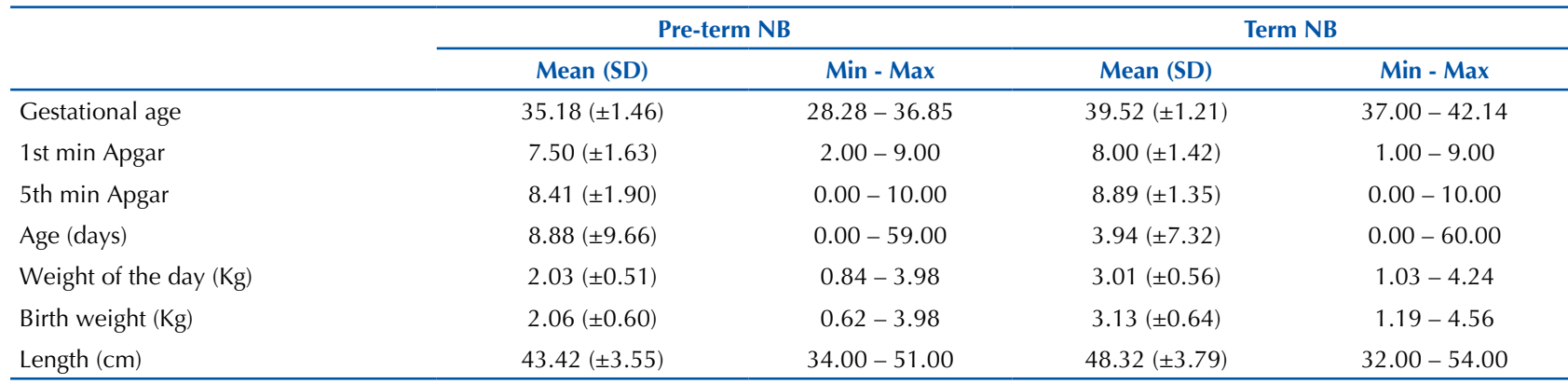

Legend: NB - newborn; SD - standard deviation; Min - minimum; Max - maximum.

Regarding the Apgar score of the PTNB, the mean was 7.5 (in the 1st minute), with an increase to 8.41 (in the 5 th minute), similar to what happens with the group of TNB, in which the mean Apgar score was 8.0 (in the 1st minute), expanding to 8.89 (in the 5th minute). Regarding the measurement of weight on the day of collection, PTNBs had a mean of $2.03 \mathrm{~kg}$, differing from TNBs by approximately $1.0 \mathrm{~kg}$. It is noticed that it is a situation similar to birth weight, which also shows a difference of approximately $1 \mathrm{~kg}$ in the means of these same groups. A similar condition is also identified in relation to the length of the NB, in which the mean in the PTNB was $43.42 \mathrm{~cm}$, almost $5 \mathrm{~cm}$ less than the mean of the term NB.

The biometric measurements of term and pre-term newborns are described in Table 2. As for nasal height, PTNBs had a mean of $1.49 \mathrm{~cm}$, while TNBs behaved similarly: $1.51 \mathrm{~cm}$ $(\mathrm{p}=0.339)$. Regarding the nasal width measurement, the groups behaved differently from each other in $0.16 \mathrm{~cm}(\mathrm{p}<0.001)$.

When assessed on the measurement of the distance from the wing of the nose to the right $\mathrm{CML}$, the newborns were also different, with a mean difference of $0.11 \mathrm{~cm}(\mathrm{p}<0.001)$. Likewise, the distance from the wing of the nose to the left CML was measured, with a difference of $0.13 \mathrm{~cm}$ between them $(\mathrm{p}<0.001)$.

Regarding the measurement of columella length, the newborns in the groups behaved in a heterogeneous manner, with a mean difference of $0.04 \mathrm{~cm}(\mathrm{p}<0.001)$. As for the columella width measurement, PTNB and TNB showed the same mean difference found in the columella length measurement $(0.04$ $\mathrm{cm})$, showing a statistically different behavior $(\mathrm{p}<0.001)$.

As for the measurement of the area of the right nasal introitus, the groups behaved differently, with a difference between the area means of $0.03 \mathrm{~cm}^{2}(p<0.001)$. The groups of newborns also behaved dissonantly in terms of the measurement of the area of the left nasal introitus, with a mean difference of $0.02 \mathrm{~cm}^{2}$ between them $(\mathrm{p}<0.001)$.

In relation to the protrusion measure of the right nasal tip, the newborns behaved in a similar way $(p=0.869)$ : the PTNB with a mean of $1.14 \mathrm{~cm}$ and the TNB of $1.14 \mathrm{~cm}$. Regarding the protrusion measure of the left nasal tip, the newborns in the groups behaved differently, with a mean difference of $0.04 \mathrm{~cm}$ between the groups $(\mathrm{p}=0.096)$. 
When the measure of the length of the right dorsum was evaluated, the groups behaved differently, with a distance between the means of $0.07 \mathrm{~cm}(\mathrm{p}=0.017)$. The same condition was perceived in relation to the measurement of the left dorsum, with a mean difference between PTNB and TNB of $0.06 \mathrm{~cm}(\mathrm{p}=0.025)$.

The association of biometric measurements with weight according to corrected age is shown in Table 3.

Table 2 - Characterization of NBs regarding the biometric points of the nasal area - Maceió, AL, Brazil, 2017.

\begin{tabular}{|c|c|c|c|c|c|}
\hline & \multicolumn{2}{|c|}{ Pre-term NB } & \multicolumn{2}{|c|}{ Term NB } & \multirow{2}{*}{ P value } \\
\hline & Mean (SD) & $95 \% \mathrm{Cl}$ & Mean (SD) & $95 \% \mathrm{CI}$ & \\
\hline Nasal Height & $1.49( \pm 0.19)$ & $1.46-1.52$ & $1.51( \pm 0.19)$ & $1.48-1.55$ & $0.339^{b}$ \\
\hline Nasal Width & $1.77( \pm 0.19)$ & $1.74-1.80$ & $1.93( \pm 0.20)$ & $1.90-1.96$ & $0.000^{b}$ \\
\hline Wing distance to right $\mathrm{CML}$ & $0.96( \pm 0.10)$ & $0.95-0.98$ & $1.07( \pm 0.10)$ & $1.05-1.08$ & $0.000^{\mathrm{a}}$ \\
\hline Wing distance to left CML & $0.97( \pm 0.12)$ & $0.95-0.99$ & $1.10( \pm 0.10)$ & $1.08-1.11$ & $0.000^{b}$ \\
\hline Columella Length & $0.41( \pm 0.08)$ & $0.40-0.43$ & $0.45( \pm 0.92)$ & $0.44-0.47$ & $0.000^{\mathrm{a}}$ \\
\hline Columella width & $0.41( \pm 0.07)$ & $0.39-0.42$ & $0.45( \pm 0.06)$ & $0.44-0.46$ & $0.000^{b}$ \\
\hline Right introitus area & $0.11( \pm 0.04)$ & $0.10-0.12$ & $0.14( \pm 0.05)$ & $0.13-0.14$ & $0.000^{\mathrm{a}}$ \\
\hline Left introitus area & $0.11( \pm 0.05)$ & $0.10-0.12$ & $0.13( \pm 0.05)$ & $0.13-0.14$ & $0.000^{a}$ \\
\hline Right tip protrusion & $1.14( \pm 0.19)$ & $1.11-1.17$ & $1.14( \pm 0.20)$ & $1.10-1.17$ & $0.869^{b}$ \\
\hline Left tip protrusion & $1.13( \pm 0.19)$ & $1.10-1.16$ & $1.17( \pm 0.22)$ & $1.14-1.21$ & $0.096^{b}$ \\
\hline Right dorsum length & $1.44( \pm 0.19)$ & $1.41-1.48$ & $1.51( \pm 0.24)$ & $1.47-1.55$ & $0.017^{b}$ \\
\hline Left dorsum length & $1.50( \pm 0.22)$ & $1.74-1.80$ & $1.56( \pm 0.25)$ & $1.52-1.60$ & $0.025^{b}$ \\
\hline
\end{tabular}

Legend: NB - newborn; CML - columellar midline; SD - standard deviation; Min - minimum; Max - maximum; Cl - confidence interval.

${ }^{a}$ Kruskal Wallis test; ${ }^{\text {b }}$ Student's t-test; Significance level $\mathrm{p}<0.05$.

Table 3 - Correlation of biometric points of the nasal area according to weight/z-score - Maceió, AL, Brazil, 2017.

\begin{tabular}{|c|c|c|c|c|c|c|c|}
\hline & \multicolumn{2}{|c|}{ Adequate } & \multicolumn{2}{|c|}{ Low weight } & \multicolumn{2}{|c|}{ Very low weight } & \multirow{2}{*}{$P$ value } \\
\hline & Mean (SD) & $95 \% \mathrm{Cl}$ & Mean (SD) & $95 \% \mathrm{Cl}$ & Mean (SD) & $\mathrm{Cl} 95 \%$ & \\
\hline Nasal Height & $1.54( \pm 0.18)$ & $1.5-1.57$ & $1.54( \pm 0.19)$ & $1.49-1.60$ & $1.43( \pm 0.19)$ & $1.40-1.47$ & $0.000^{b}$ \\
\hline Nasal Width & $1.96( \pm 0.19)$ & $1.92-1.99$ & $1.86( \pm 0.19)$ & $1.8-1.91$ & $1.70( \pm 0.17)$ & $1.67-1.74$ & $0.000^{b}$ \\
\hline Wing distance to right $\mathrm{CML}$ & $1.09( \pm 0.95)$ & $1.07-1.10$ & $0.99( \pm 0.08)$ & $0.97-1.02$ & $0.93( \pm 0.09)$ & $0.91-0.95$ & $0.000^{b}$ \\
\hline Wing distance to left CML & $1.11( \pm 0.09)$ & $1.10-1.13$ & $0.99( \pm 0.12)$ & $0.96-1.03$ & $0.95( \pm 0.10)$ & $0.93-0.97$ & $0.000^{b}$ \\
\hline Columella Length & $0.45( \pm 0.08)$ & $0.44-0.47$ & $0.42( \pm 0.09)$ & $0.40-0.45$ & $0.42( \pm 0.09)$ & $0.40-0.43$ & $0.005^{\mathrm{a}}$ \\
\hline Columella width & $0.46( \pm 0.06)$ & $0.45-0.47$ & $0.43( \pm 0.07)$ & $0.41-0.45$ & $0.39( \pm 0.06)$ & $0.38-0.41$ & $0.000^{b}$ \\
\hline Right introitus area & $0.14( \pm 0.05)$ & $0.13-0.15$ & $0.11( \pm 0.04)$ & $0.10-0.12$ & $0.11( \pm 0.04)$ & $0.10-0.12$ & $0.000^{a}$ \\
\hline Left introitus area & $0.14( \pm 0.05)$ & $0.13-0.14$ & $0.11( \pm 0.05)$ & $0.10-0.12$ & $0.11( \pm 0.04)$ & $0.10-0.12$ & $0.000^{\mathrm{a}}$ \\
\hline Right tip protrusion & $1.14( \pm 0.21)$ & $1.10-1.17$ & $1.19( \pm 0.18)$ & $1.14-1.24$ & $1.11( \pm 0.18)$ & $1.07-1.14$ & $0.054^{b}$ \\
\hline Left tip protrusion & $1.17( \pm 0.22)$ & $1.13-1.21$ & $1.21( \pm 0.19)$ & $1.16-1.27$ & $1.09( \pm 0.18)$ & $1.06-1.13$ & $0.001^{b}$ \\
\hline Right dorsum length & $1.52( \pm 0.23)$ & $1.48-1.55$ & $1.49( \pm 0.21)$ & $1.43-1.55$ & $1.41( \pm 0.20)$ & $1.37-1.45$ & $0.002^{b}$ \\
\hline Left dorsum length & $1.56( \pm 0.24)$ & $1.52-1.60$ & $1.56( \pm 0.23)$ & $1.50-1.62$ & $1.48( \pm 0.22)$ & $1.43-1.52$ & $0.020^{b}$ \\
\hline
\end{tabular}

Legend: CML - columellar midline; SD - standard deviation; Min - minimum; Max - maximum; Cl - confidence interval.

${ }^{a}$ Kruskal Wallis test; ${ }^{\text {b }}$ Student's t-test; Significance level $\mathrm{p}<0.05$.

Table 3 shows the correlation between biometric measurements and weight according to the newborn's corrected gestational age according to weight on the day of collection, with the following classification: newborns with very low weight for age, low weight for age and adequate weight for age, based on the WHO z-score scale ${ }^{(12)}$.

As for the nasal height, the groups with adequate weight and low weight had a mean of $1.54 \mathrm{~cm}$, while the group of very low weight showed a mean difference of less $0.11 \mathrm{~cm}$ $(\mathrm{p}<0.001)$. Regarding nasal width, the three groups had different mean values, with the largest distance found between the means being in the groups of adequate weight and low weight, with a difference of $0.26 \mathrm{~cm}(\mathrm{p}<0.001)$.

Regarding the distance from the wing of the nose to the right CML, the groups presented different mean values, with the greatest difference between the means of the groups of adequate weight and very low weight, with a value of 0.16 $\mathrm{cm}(\mathrm{p}<0.001)$. As for the distance from the wing of the nose to the left CML, the groups of adequate weight and low weight showed an mean difference of $0.12 \mathrm{~cm}$, whereas the group of very low weight had a mean of $0.95 \mathrm{~cm} p<0.001$.

Regarding the length of the columella, the groups low weight and very low weight had values of mean of 0.42 $\mathrm{cm}$, differing from the group of adequate weight in 0.03 $\mathrm{cm}(\mathrm{p}=0.005)$. Regarding the width of the columella, the means between the groups were different, with the greatest difference between groups of adequate weight and very low weight, with a value equal to $0.07 \mathrm{~cm}(\mathrm{p}<0.001)$.

Regarding the area of the right nasal introitus, the low weight and very low weight groups had similar area mean, differing from the appropriate weight group in $0.03 \mathrm{~cm}^{2}$ $(p<0.001)$. It is noteworthy that the same measures are repeated on average in relation to the area of the left introitus, demonstrating bilateral symmetry $(\mathrm{p}<0.001)$. 
As for the protrusion of the right nasal tip, the highest mean was that of the low birth weight group, with $1.19 \mathrm{~cm}$, showing a greater difference in means when compared to the very low weight group, with the value of $0.08 \mathrm{~cm}(\mathrm{p}=0.054)$. Likewise, in the protrusion of the left nasal tip, the low weight group also had a higher mean value, differing with a greater distance from the means of the very low weight group, in $0.12 \mathrm{~cm}(\mathrm{p}=0.001)$.

As for the length of the right nasal dorsum, the greater difference between the means was in the groups of adequate weight and very low weight, moving away by $0.11 \mathrm{~cm}$, while the low weight group had a mean of $1.49 \mathrm{~cm}(\mathrm{p}=0.002)$. Regarding the protrusion of the left nasal tip, the groups of adequate weight and low weight had equal means, with a value of $1.56 \mathrm{~cm}$, differing from the mean of the group of very low weight in $0.08 \mathrm{~cm}(\mathrm{p}=0.020)$.

\section{DISCUSSION}

The characteristics of the population studied in this research show similarity in the distribution by gender in the two groups of newborns. There was also a high number of cesarean sections in both groups, which disagrees with what is advocated by the World Health Organization (WHO), which states that cesarean surgery rates should be between 10 to $15 \%$ of all deliveries ${ }^{(12)}$.

The mean Apgar scores found in this study was higher in TNB compared to PTNBs, both of which showed an increase in mean indexes in the 5 th minute. This situation is also detected in the literature, in which the proportion of late PTNBs who had lower Apgar scores (less than 7) in the 1st and 5 th minutes was higher, when compared to the $\mathrm{TNB}^{(13)}$.

The difference between the mean birth weight and the weight on the day of data collection of the newborns participating in this research was maintained between the groups. Since the greatest growth of the fetus occurs between 22 and 40 weeks of gestation ${ }^{(14)}$, the PTNB has this stage of intrauterine development interrupted, leading to low birth weight and showing differences when compared to the TNB.

The same occurs with the length of the newborns, as there is a rapid intrauterine growth in the last trimester of pregnancy, which causes premature births to present lower values. The best growth rate for this group is when its postbirth growth is compared with the equivalent of what should occur in intrauterine environment ${ }^{(14)}$.

Biometric measurements were assessed for maturity and weight classification. Nasal height and width are measures that can present significant interferences in the shape of the newborn's nose, affecting the positioning and fixation of devices (prongs) and/or the appearance of nasal lesions. Especially on the nasal width, in the distance of maximum expansion between the wings of the nose, a significant difference can be observed between TNB and PTNB. Premature newborns may have smaller widths, interfering with the dimensions and anatomical components included in the entire extension. These measures also suffer from interference when associated with weight. Nasal height is significantly lower in very low birth weight newborns, while nasal width is progressively affected by weight in the three segments.
The distance from the columellar midline to the right or left nose wing is a measure that is affected by the width of the nasal introitus, the width of the columella itself or the thickness of the nose wing. The measure is of great importance in the possible injuries that can arise with the use of frequent devices, mainly in injuries in the lateral structures, either more central, as the faces of the nasal septum, or more distal, as the structure of the wing of the nose. This has a lower occurrence of injuries due to its greater expansive capacity with increased pressure ${ }^{(15)}$, but when affected by severe injuries, it can cause irreversible damage due to its tissue characteristics. In this study, this distance presents significant differences between the groups, with the TNB showing larger measures than PTNB, in addition to showing a progressive increase in dimensions, when observed in relation to the newborn's weight classification.

The length and width of the columella are measures of a prominent structure when the nasal lesion develops. Columella and nasal septum are the main structures associated with nasal lesions correlated with the use of prongs ${ }^{(16)}$, which is due to their location. The columella extends from the tip of the nose to the lip, medially separating the nostrils. Its inclination is related to the nasolabial angle, also called septo-labial ${ }^{(17)}$. The frequent involvement of this structure can lead, in more severe cases, to partial or complete loss of the nasal septum, with relevant consequences for the organ's functionality and the child's self-image.

The knowledge and use of the dimensions of this structure can favor the prevention of injuries. In this study, columella width and length measurements showed a significant difference between TNB and PTNB, the latter group having the smallest measurements. Also, in relation to the newborn's weight classification, the specific measurements of the columella differ, showing, mainly in width, the difference between all groups of newborns by weight. This may mean that more premature and low weight NBs have more delicate structures and, consequently, are more susceptible to injuries.

The area of the nasal introitus is a two-dimensional measure relative to the space of the nostrils. It has great relevance in evaluating the effectiveness of the current models of devices available on the market and in their association with nasal injuries. It is known that the use of nasal prongs is associated with lesions in the medial part of the nasal septum, indicating that this point is under greater pressure from the prongs ${ }^{(15)}$.

The areas of nasal introitus were different in this study in the two groups of newborns, with larger areas in TNB compared to PTNBs. There is also a difference in weight: newborns with adequate weight showed larger areas than the other groups. The areas of the right and left nasal introitus show very similar values, sometimes with equal averages, pointing to the bilateral symmetry that the nostrils show, regardless of the NB's maturity or weight.

There are expectations that new designs of prongs, which maintain therapeutic efficacy, are a way to minimize the injuries caused by their use ${ }^{(15)}$. Considering the areas of the nasal introitus for the formulation of more anatomical device models may represent a tool for technological innovation in 
health that favors the reduction of damages caused by the continuous use of this ventilatory therapy.

The protrusion of the nasal tip is a linear measure that shows the longitude of the wing of the nose, from the alar implantation to the nasal tip. This measure brings indicators, even if indirect ones, regarding the capacity of devices to accommodate in the nostril, since the correct size and positioning of the prong avoids the extension of the material, improving the ventilation capacity ${ }^{(1)}$.

Knowing the dimensions of the protrusion of the nasal tip can help in the construction of protectors that reveal wide action in relation to all points of injury, including those places reserved for fixing the equipment to ensure positive pressure in the airways. In this study, the protrusion of the right and left nasal tip did not differ between the groups of TNB and PTNB. However, when evaluated in relation to weight classification, these measures were different, varying between them.

Measuring the length of the nasal dorsum has also an impact on the adaptation of nasal devices. Smaller lengths recur in shallower noses, with little amplitude of the nasal cavities. As the poor accommodation and/or fixation of the devices to the nostrils can cause friction and, consequently, injuries $^{(6)}$, paying attention to the dimensions of the dorsum length can influence the choice of anatomically proper devices for the various nasal structures.

The lengths of the right and left dorsum were different in the groups of TNB and PTNB, with higher values among those who did not have prematurity. Regarding weight classification, the length of the nasal dorsum was longer in newborns of adequate weight compared to the other classifications.

\section{CONCLUSION}

Obtaining and analyzing the biometric measurements of the nasal area of pre-term and term newborns made it possible to point out differences between the biometric measurements according to maturity and weight classification.

Thus, one sought to contribute to the development of technologies aimed at preventing nasal injuries resulting from therapies used to promote oxygenation effectively, as well as to improve the quality of care provided to newborns, with a view to safe procedures and injury prevention.

Thus, the measures will be a basis for proposing a model of nasal protector and other anatomical devices that can contribute to improving the quality of ventilatory therapy by prongs, reducing cases of nasal injuries by these devices, in addition to favoring technological innovation in the care of neonatal nursing.

\section{RESUMO}

Objetivo: Correlacionar as medidas biométricas da região nasal de recém-nascidos prematuros e a termo e fornecer parâmetros para um modelo de protetor nasal. Método: Estudo descritivo de corte transversal, realizado nas unidades de alojamento conjunto, cuidados intermediários e intensivos neonatais de um hospital de Maceió, Alagoas, com 300 recém-nascidos, divididos em dois grupos: 150 a termo e 150 prematuros. Utilizaram-se dados da história neonatal e 1200 fotografias digitais para as medidas biométricas. Resultados: Os grupos foram homogêneos quanto ao sexo, peso e comprimento do recém-nascido. As medidas de largura nasal, distância da asa do nariz à linha média columelar direita e esquerda, comprimento e largura da columela, área do introito nasal direita e esquerda, comprimento do dorso nasal direito e esquerdo apresentaram-se diferentes quando comparadas em grupos de acordo com a idade gestacional, e quanto às faixas de peso - muito baixo peso, baixo peso e peso adequado a idade gestacional ( $\mathrm{p}<0,05)$. Conclusão: Os dados obtidos fornecem parâmetros para criação de protetor nasal para recém-nascidos em uso de pronga, considerando aspectos anatômicos.

\section{DESCRITORES}

Recém-Nascido; Nariz; Proteção; Tecnologia; Enfermagem Neonatal.

\section{RESUMEN}

Objetivo: Correlacionar las medidas biométricas de la región nasal de neonatos prematuros y a término y ofrecer parámetros para un modelo de protector nasal. Método: Se realizó un estudio descriptivo de corte transversal en unidades de internación conjunta de cuidados intermediarios e intensivos neonatales de un hospital de Maceió, Alagoas, con 300 recién nacidos, divididos en dos grupos: 150 a término y 150 prematuros. Para las mediciones biométricas se utilizaron datos de la historia neonatal y 1.200 fotografías digitales. Resultados: Los grupos eran homogéneos en cuanto a sexo, peso y longitud del recién nacido. Las medidas de la anchura nasal, la distancia del ala de la nariz a la línea media del subtabique, lado derecho e izquierdo, la longitud y la anchura del subtabique, el área de las fosas nasales derecha e izquierda, la longitud del tabique nasal lado derecho e izquierdo eran diferentes cuando se compararon en los grupos según la edad gestacional, y en los rangos de peso: peso muy bajo, peso bajo y peso adecuado para la edad gestacional ( $\mathrm{p}<0,05)$. Conclusión: Los datos obtenidos brindan parámetros para la creación de un protector nasal para recién nacidos que utilizan prongs, considerando los aspectos anatómicos.

\section{DESCRIPTORES}

Recién Nacido; Nariz; Protección; Tecnología; Enfermería Neonatal.

\section{REFERENCES}

1. Loh LE, Chan YHC, Chan I. Ventilação não-invasiva em crianças: uma revisão. J Pediatr (Rio J). 2007;83(2 Supl.):S91-9. doi: https://doi. org/10.1590/S0021-75572007000300011

2. Morley C. Que dispositivo CPAP nasal neonatal devemos utilizar em lactentes com taquipneia transitória do recém-nascido? [editorial]. J Pediatr (Rio J). 2011;87(6):466-8. doi: https://doi.org/10.1590/S0021-75572011000600002

3. Alves A, Santos ERS, Souza TG. Prevenção de lesões nasais secundárias ao uso de pressão positiva contínua nas vias aéreas (cpap) em recém-nascidos prematuros de extremo baixo peso. Rev Univ Vale Rio Verde. 2013;11(2):209-17. doi: http://dx.doi.org/10.5892/ruvrd. v11i2.251255

4. Günlemez A. Effect of silicon gel sheeting in nasal injury associated with nasal CPAP in preterm infants. Indian Pediatrics. 2010;47:265-67. 
5. Edsberg LE, Black JM, Goldberg M, McNichol L, Moore L, Sieggreen M. Sistema de estadiamento por pressão do painel consultivo de úlcera por pressão revisado. J Wound Ostomy Continence Nurs. 2016;43(6):585-97.

6. Nascimento RM, Ferreira ALC, Coutinho ACFP, Veríssimo RCSS. The frequency of nasal injury in newborns due to the use of continuous positive airway pressure with prongs. Rev Latino Am Enfermagem. 2009;17(4):489-94. https://doi.org/10.1590/S0104-11692009000400009

7. Nunes CR, Castro SB, Motta GCP, Silva AM, Schardosim JM, Cunha MLC. Método de prevenção de lesão nasal causada por CPAP em recém-nascido pré-termo: relato de caso. Rev HCPA. 2012;32(4).

8. Santos SV, Costa R. Prevention of newborn skin lesions: knowledge of the nursing team. Texto Contexto Enferm. 2015;24(3):731-9. doi: https://doi.org/10.1590/0104-07072015011230014

9. Instituto Nacional da Propriedade Industrial, Diretoria de Patentes. Resolução n. 85-13. Diretrizes de exame de patente de modelo de utilidade [Internet]. Brasília: INPI; 2012 [citado 2017 mar. 17]. Disponível em: http://www.inpi.gov.br/legislacao-arquivo/docs/ resolucao_85-13-anexo_diretrizes_mu.pdf

10. Taub PJ, Baker SB. Rinoplastia: atlas de cirurgia plástica. Porto Alegre: AMGH; 2013.

11. Brasil. Ministério da Saúde; Secretaria de Atenção à Saúde, Departamento de Atenção Básica. Atenção ao pré-natal de baixo risco. Brasília; 2013. (Cadernos de Atenção Básica, 32).

12. Organização Pan-Americana da Saúde; Organização Mundial de Saúde. Declaração da OMS sobre as taxas de cesáreas. Brasília: OPAS/ OMS; 2015.

13. Almeida MFB, Guinsburg R, Costa JO, Anchieta LM, Freire LMS, Campos Junior D. Procedimentos de ressuscitação ao nascimento em prematuros tardios. J Perinatol. 2007; 27:761-5.

14. Fenton TR, Kim JH. A systematic review and meta-analysis to revise the Fenton growth chart for preterm infants. BMC Pediatr. 2013;13:59. doi: $10.1186 / 1471-2431-13-59$

15. Yong SC, Chen SJ, Boo NY. Incidence of nasal trauma associate with nasal prong versus nasal mask during continuous positive airway pressure treatment in very low birthweight instants: a randomized control study. Arch Dis Child Fetal Neonatal. 2005;90(6):F480-3. doi: 10.1136/adc.2004.069351

16. Ota NT Davidson J, Guinsburg R. Lesão nasal precoce pelo uso da pronga nasal em neonatos prematuros de muito baixo peso: estudo piloto. Rev Bras Ter Intensiva. 2013;25(3):245-50. doi: http://dx.doi.org/10.5935/0103-507X.20130042

17. Furtado IR. Morfologia nasal: harmonia e proporção aplicadas à rinoplastia. Rev Bras Cir Plást. 2016;31(4):599-608. doi: http://www. dx.doi.org/10.5935/2177-1235.2016RBCP0089 